\title{
MODERATING INFLUENCE OF TRAINING AND DEVELOPMENT ON ENTREPRENEURIAL PERFORMANCE
}

\author{
Solomon Akpoviroro Kowoㅁ, Olufemi Amos Akinbola², Olalekan Owotutu Sabitu ${ }^{3}$ \\ ${ }^{1}$ Department of Business and Entrepreneurship, Kwara State University, Malete Nigeria \\ kowosolomon@gmail.com \\ ${ }^{2}$ Department of Business Administration, Federal University of Agriculture, Abeokuta Nigeria \\ femiakinbola@gmail.com \\ ${ }^{3}$ Department of Business Administration, Ogun State Institute of Technology Igbesa, Nigeria \\ olatoyosim@gmail.com
}

\begin{abstract}
This study assessed the moderating effect of training and development on entrepreneurial performance of Micro, Small and Medium Enterprises (MSMEs) in Nigeria considering the Bank of Industry and Small and Medium Enterprises Development Agency of Nigeria (SMEDAN). Two hypotheses were tested in this study reflecting training and development in Nigeria and Ethical practices of Training and Development impacts on behavioral outcomes of entrepreneurs. The paper puts to test, the preceding assertions with the aid of Kruskal Wallis test. From the test, the study refutes the former assertions on the reasoning that P-values were less than 5\% level of significance. This showed that the impact of ethical training and development would be more significant if the young entrepreneurs had earlier exposure from secondary to tertiary education level to make better entrepreneurs in Nigeria. The study observed that the Nigerian educational system has contributed positively to the area of training and development which has enhanced entrepreneurial performance in Nigeria. The study recommends that training and development programme should focus on developing creative or innovative individuals who can help to move the nation forward. A Self-reliant person is a creative individual.
\end{abstract}

Keywords: Training and Development, Entrepreneurial Performance, SMEDAN.

(JEL Classification: M53, M1)

\section{INTRODUCTION}

The need for entrepreneurs to pay attention to training and development has become necessary because of challenges beings faced by entrepreneurs in their various business environment (Shaker, 2011; Thomas 2013; Subchat, 2008). Stillman (2003) defined entrepreneurship education as an effective means of providing human beings with skills relevant to social needs of sustainable national and individual development. Harnessing of other factors for formation of business venture is made possible in youths through the idea and skills acquired in entrepreneurship education. Such other factors are capital, site of a business enterprise, material needed among others (Spender, 2002). Entrepreneurship education has been viewed as an effective tool for entrenching sustainable development (GEM, 2008). Kowo \& Kadiri (2018) asserted that entrepreneurship education inculcates in youths the efficient methods of distributing goods and services to the consumer and the desirable social and cultural behaviors. Improvement of Managerial efficiency entrepreneurship education equips the recipients with relevant skills, behavior, business attitude and curbs managerial deficiency if properly channeled. Entrepreneurship education creates glaring relationship between institutions and industries as the operators of industries allow the students of entrepreneurship education to gain practical work experience.

All employees need some form of training that gives them a wider general knowledge of new techniques that will be beneficial to both the employer and employees. Klapper (2004) posit that effective training programme can improve efficiency and morale, develop supervisors and decrease amount of supervisors needed. Ogundele (2000) perceived 
entrepreneurship education as the greatest force that can be used to achieve quick development of the nation's economic resources. Any work that involves physical exertion is still frowned at in the country. Snyder (2011) Opined that efficient management of resources entrepreneurship education inculcates in individuals skills enable them to manage resources efficiently. Waste and misuse of resources that usually have influence on business are properly guided against; because of the knowledge of efficient application of resources which entrepreneurship education equips individuals. Stewart (1998) emphasized that the objectives of management training is to improve current performance and provide trained staffs, skills to meet present and future needs. He further explained that when training is effective individual need will be determined. Management training yield new techniques, provide for succession, thus ensuring that qualified replacements are available, lead to reduction in waste, scrap rate and improve machine utilization (Ogundele, 2012).

The quality of human resources that is available in an entrepreneur organization depends on the processes of recruitment, training and development of the workforce. The procedure of recruiting good staff into the organization, how to train new employees to be useful in their contribution to the organization and the development of management staff should be the concern of all organizations (Ajonbadi, 2017). Ogundele (2005) emphasized on the need for management and other training and development institution in Africa to focus on developing creative or innovative individuals who can help to move the nation forward. Otokiti (2013) posit that except employees are disciplined and exhibit ethical behavior, all training and development efforts will produce little or no results. It is now an important phenomenon for entrepreneurs to utilized effective management training which is a source of wealth for entrepreneurial growth and expansion of new markets in the regions (Starr \& Fondas, 1992; Stefanovic et al, 2009; Galloway \& Brown, 2002).

\section{MATERIALS AND METHODS TRAINING AND DEVELOPMENT}

Ajonbadi (2017) postulates that training and development is the process of modifying behavior in organizations which represent entrepreneurial function. Decades of research considered training as the organized procedure by which people learn knowledge or skills for a definite purpose. Training means to educate someone narrowly by instruction drill and discipline (Brown, 2002). Snyder (2011) regarded training as applying principally to the improvement of skills and hence of learning how to perform specific tasks. Training is the systematic development and improvement of an individual's ability to perform specific task or job (Shaker, 2011; Thomas, 2013). Entrepreneurs are agent of social technological and economic changes, entrepreneurial training and development will encourage Nigerian to become job creators, rather than job seekers. It will equip them with skills for innovation and improvement of ideas and skills (Olayemi \& Ogundele, 2004). Adewunmi (2004) posit that within the context of globalized economy, nation states and their economies are being reorganized into one big production unit, where transnational corporations are free to operate virtually on their own terms and without much regard to national legislations. Ogundele (2004) observes that for success of National Economic Empowerment and Development Strategy (NEEDS) we require a new development effort, this he calls spiritual capitalism, which will involve among other things, calling out the best from every Nigerians.

Armstrong (2009) notes that globalization has several elements with varying contending demands on national development; this range from self-reliance, ethics or discipline behavior, man power development, entrepreneur stream development to several others. Training brings improvement to employee's skills, leadership with vision and not mafia managers will cap these suggested improvement (Moberg, 2014; Tarvis, 2017). Ethical training is supposed to have immediate and direct impacts on behavior modification; this is because it is concerned with building the individual, desirable societal or organizational set of valued behavior (SMEDAN, 2012; Ajonbadi, 2014; Stillman, 2003). Since education is concerned with increasing general knowledge and understanding of total environment, therefore the major burden of education falls upon our formal school system. (Galloway \& Brown, 2002; Swierczek \& Ha, 2003). Development as a planned process of providing employees with many experiences desired to enhance their contribution to organizational goals (Klapper, 2004; kuratkho, 2005)

\section{TYPES OF TRAINING}

Training has several definitions that are best appreciated by investigating the various objectives of the training. In this context, Moberg (2014) and Armstrong (2009) categorized the different types of training as follows:

- Technical skills training develops skills, such as manual skills and information technology (IT) skills that are needed to perform work duties, for example, during apprenticeships.

- Trainer training supports trainers in developing their skills in order to achieve training goals.

- Performance management helps workers upgrade their job performance by providing them with skills that reduce waste, improve the quality of work and so on.

- Personal training enables the person to manage his/her life and career, such as assertiveness, coaching, communication and time management.

- Problem solving/decision-making teaches individuals to solve difficulties by facing them in a systematic way.

- Management training helps managers improve their Leadership management skills by studying problems and find solutions.

- Mandatory training is determined to be essential by an organization because it is necessary to reduce organisational risks and comply with policies and government guidelines. 
- Interpersonal skills support the development of leadership, coaching and communication skills, as well as interpersonal skills, such as team building, group dynamics and neurolinguistic programming.

- Business function training improves the knowledge and skills required for various business functions.

- Organisational procedures training informs and teaches employees about organisational practices, such as health and safety, performance management, equal opportunities, managing diversity policies and practices, induction programmes and so on.

\section{EVOLUTION AND EVALUATION OF TRAINING AND DEVELOPMENT IN NIGERIA}

Ogundele (2004) Pointed that the origin of serious concern for training and development in Nigeria can be dates back to April 1959 when the federal government set up the Ashby commission on the eve of independence to conduct an investigation into Nigeria needs in the field of postschool certificate and higher education over the next twenty years. The deficiencies of the Ashby was a result of lack of balance both in structure and in geographical distribution, Ashby reports recommend a broad based university education. It demands that professional qualification in accounting, personnel and banking should be obtained in the universities, Ashby made direct recommendation on management studies. Ashby also recommend that institute should make sure they make available full time commercial courses. Higher management should be taught at the postgraduate. University of Lagos was arranged for courses leading to commerce and business administration among others (Kowo, Sabitu \& Adegbite, 2018).

Nigeria Management Group brought non formal employment training in 1961; the group was renamed in 1962 as Nigeria Institute of Management which was established as a nonprofit making association of professional managers. The Second National Development Plan 19701975 brought the establishment of key manpower training and development programs and institutions (Udo-Aka, 1987). (ITF) was established under decree no 47 of 1971 which are set up for four broad categories which are supervisory and management training; employer owned training institutions; trade group training programme and in company training programme (Ogundele,2012).Nigeria Institute of Management(NIM) services and programmes include management consultancy, executive selection, publication, annual national management conference and training, management research and offering courses to help practicing managers for concepts, techniques and method acquired(Otokiti, 2013).

According to Ajonbadi (2017) The Administrative Staff College of Nigeria (ASCON) was set up by decree no 39 of 1973 with the following functions which include establishing and maintaining library; conducting management research; providing exchange ideas among management and administrators for better understanding and promotion. Adewunmi (2004) postulated that Center for Management Development (CMD) contributed immensely in the role of managerial resources which can be categorized under promotion of entrepreneurial role; coordination of activities of private and public institutions involved in management education training and development and the action role which aim at improving the quality of management education, training and development. Osuagu (2006) Emphasized that National Institute for Policy and Strategies (NIPSS) was established under Decree No 20 of 1st January 1979 to conduct conferences, workshops and seminars for leaders in public services and private sectors with certificates awarded when necessary.

Ogundele (2012) noted that evaluation is determined whether changes in skills, knowledge and attitudes have taken place as a result of training and development. This is so because; first, there are problems that arise from the nature of behavioral sciences which are not exact, and second, there are problems that arise from the variety of factors influencing employees and managers (Sule, 2014). Ajonbadi (2014) stated that from 1960 to date there has been phenomenal increase in training and development activities. He emphasized that training and development has expanded horizontally and vertically. It is obvious that training and development have a moderating influence on organizational performance and organizational member's effectiveness. Sule (2014) postulates that result of trainers' intervention are below expectation because a large number of these trainers themselves need to be trained. Another factor affecting effectiveness in the area of training and development is the concept of reflecting the Federal character in both the public and private organizations. General indiscipline among Nigerian workforce in all sectors of the economy has been a negative factor that affects training and development in Nigeria. Supervisors and leaders in workshop lack knowledge to do the job and many have lost their sense of identification (Osuagu, 2006).

Ajonbadi (2017) highlight the factors affecting training and development in Nigeria which includes among others: Programmes were largely in the traditional management areas; The existing western management education and training programme in Nigeria is diffused; Inadequate of research grants and facilities limited the rate and size of management education and training research; The dominant use of foreign resources seemed to accept the concept of interchangeability of management education and training knowledge. Leadership problem in all organization sectors, from public, private enterprises, armed forces, political and religious organization has a negative influence on effectiveness of training and development. Most of them are leaders who say one thing and practice an entirely different thing which has contributed to high level of indiscipline in Nigeria organizations. (Otokiti, 2013; Ogundele, 2004; Melodi, 2006) 


\section{BOOSTING ENTREPRENEURIAL PERFORMANCE THROUGH ENTREPRENEURSHIP TRAINING AND DEVELOPMENT}

Dawson \& Henley (2012) revealed that, through training and development, entrepreneurs can be taught, or at least enhanced. This position is corroborated by Ogundele (2012) who notes that entrepreneurial ability is neither mystical nor magical but rather something that could be learned. A country with qualitative entrepreneurial education will likely produce successful entrepreneurs. The terms 'entrepreneurship education' and 'entrepreneurship training' are generally used synonymously (Lin et al, 2011; Lalkaka, 2003).It includes various programmes targeted at changing the world view of learners, from job seekers to job creators. Amongst other things, entrepreneurship training seeks to promote creativity, risk-taking, leadership, team-spirit, autonomy, sense of initiative, self-employment, self-confidence and innovation; it is a combination of all these features which set entrepreneurship education apart from general economic or business studies (Lee,Chang\&Lim,2005;Matuluko,2015). Unlike ordinary business management, entrepreneurship involves elements of risk taking, creativity and innovation (Lin et al, 2011).

\section{EFFECT OF TRAINING AND DEVELOPMENT ON ENTREPRENEURIAL STRATEGIC LEADERSHIP}

Several decades of research have shown leadership as vital to Entrepreneurs. A review of the leadership literature in Africa shows descriptive but not empirically and conceptually in-depth studies of strategic leadership which is a major requirement for appreciating executive behaviors in SMEs (Lee et al, 2005). Effective training and development will enhance entrepreneurial strategic leadership while competing in turbulent and unpredictable environments. In order to succeed and survive these turbulent business environments, entrepreneurs need to adapt to these environmental changes by means of strategic leadership (Matuluko, 2015).

Armstrong (2009) noted that one of the reasons for the death of SMEs is their failure to make use of training and development for effective leadership practices. A combination of managerial leadership and visionary leadership is a factor that determines Small and Medium Enterprises' success performance. In today's competitive environment, running a small business by means of strategic leadership is not just a good idea; it is a requirement for success and sustainability (Ogundele, 2012). The inability of entrepreneurs to apply the strategic leadership skill through training and development fully in their business will consequently result in low commitment of stakeholders such as banks and other investors. (Swierrczek \& Ha, 2003; Starr \& Fondas, 1992; Stefanovic et al, 2009; Zahraden, 1981)

\section{SUGGESTEDSOLUTIONTOTHE PROBLEMS OF TRAINING AND DEVELOPMENT PROGRAMMES IN NIGERIA.}

- Ogundele \& Olayemi (2004) suggested that interest in research work should increase in the area of training and development, relevance and functionalism should be criteria for accepting training and development in Nigeria. Increase in research work in the area of entrepreneurial training and development will provide a unique solution to Nigeria entrepreneurial existing problems in the aspects of training and development because it will helps entrepreneurial to define their standard and purpose.

- Osuagu (2006) suggested that there should be training in vocational areas to improve functional literacy skills of talented entrepreneurs and youths which should be the responsibility of the local government by establishing trade centers, craft schools and organizing running craft.

- The Federal and State government should give both moral and adequate financial supports to research institutes and universities so as to enable them guide the citizens in molding good educational programme for development of our nation. Presently we have over 100 universities with the federal democratic government approval of new universities which form a basis for positive development for the future of Nigeria (Adewunmi, 2014).

- Research has indicated that job experience and skills are more effective than any other instrument. It is important to have appropriate training and development techniques of conferences and seminars. Training ranks lowest among the named techniques (SMEDAN, 2012).

- Research has also shown that structured and directive styles were found to be more effective of minimizing participant's conflict, increasing effective communications and achieving good cohesiveness. With this it is obvious that there is need for well-structured training programme which will encourage a favorable attitude towards trainer than a less structured trainer style (Ugoji, Mordi and Ajonbadi, 2014)

- Managers are not born but made; training and development are concerned with modifying behavior in organization. There should be ethical training and development that will have direct impact on behavior modification and societal or organizational set of valued behavior. Ethical education, training and development should be employed as instrument of innovative change in the society which will eradicate or reduce the pattern of fraud at workplace in Nigeria enterprises (Ogundele \& Opeifa 2004).

\section{METHODS AND THE SAMPLE}

The case study for this research work was the Bank of Industry and Small and Medium Enterprises Development Agency of Nigeria (SMEDAN). The main objectives of the Bank of Industry is to promote industrialization and entrepreneurship development by assisting in the aspect of finance and advising 
the micro, small and medium entrepreneurs(MSMEs) and large enterprises in Nigeria. Moreover SMEDAN is a government agency with the objectives of providing entrepreneurship education in the area of training and development to micro, small and medium entrepreneurs (MSMEs). The population for this study is the MSMEs of 981 respondents of Small and Medium Enterprises Development Agency of Nigeria (SMEDAN) and the Bank of Industry (BOI) located in South West Nigeria. The use of primary data through the administration of structured questionnaire. Non-parametric test of Kruskal-Wallis of K-Independent sample test was used to test the independency of each hypothesis formulated because of the Ordinal and non-stringent assumptions nature of data (Creswell, 2009; Easterby-Smith et al, 2011)

\section{RESULTS AND DISCUSSION ANALYSIS AND INTERPRETATION OF RESULT}

Table 1: Moderating Influence of the Nigerian educational system on entrepreneurial performance in the area of training and development in Nigeria

\begin{tabular}{|l|l|l|l|}
\hline $\begin{array}{l}\text { Importance of Education } \\
\text { on training and } \\
\text { development in Nigeria }\end{array}$ & Frequency & $\begin{array}{l}\text { Valid } \\
\text { Percentage }\end{array}$ & $\begin{array}{l}\text { Cumulative } \\
\text { Percentage }\end{array}$ \\
\hline SD & 11 & 1.15 & 1.15 \\
\hline D & 43 & 4.48 & 5.63 \\
\hline U & 68 & 7.076 & 12.076 \\
\hline A & 409 & 42.56 & 55.27 \\
\hline SA & 430 & 44.72 & 100 \\
\hline TOTAL & 961 & 100 & - \\
\hline
\end{tabular}

Source: Field Survey (2018)

$S D=$ Strongly Disagree, $D=$ Disagree, $U=$ Undecided, $A=$ Agree, $\mathrm{SA}=$ Strongly Agree.

The result shown that 409 (42.56per cent) and 430 (44.72per cent) of the respondents believed that the Nigerian educational system has influence on training and development.

Table 1 above shows that 11 respondents representing 1.15 percent and 43 respondents representing 4.48 percent strongly disagreed and disagreed respectively of the opinion that the Nigerian educational system has influence on entrepreneurial performance of MSMEs in Nigeria. It can be observed that a total number of 68 respondents were undecided as to the relevance of the Nigerian educational system to entrepreneurial performance in the area of training and development in Nigeria.

Table 2: Kruskal Wallis Test

\begin{tabular}{|l|l|l|}
\hline Kruskal Wallis Test & Value & Asymptotic. Sig. (2-sided) \\
\hline Chi-square & 26.908 & $0.00351^{* *}$ \\
\hline N of Valid Cases & 961 & \\
\hline
\end{tabular}

Source: Field Survey $(2018) * 0.05=$ Level of significant

Furthermore the assertion that Nigerian educational system has not been contributing towards training and development with the P-value of the Pearson chi-square gotten from 3 independent samples Kruskal Wallis test in table 2 above. The P-value $=0.00351$ estimated from the test-statistic is less than 0.05 ( $5 \%$ level of significant) assertion that Nigerian educational system have not been contributing towards entrepreneurship development is invalid. The study shows that the Nigerian educational system has contributed positively to the area of training and development which has enhanced entrepreneurial performance in Nigeria and this is in accordance with the findings of Ogundele (2012)

Table 3: Ethical Training and Development have direct impact on behavior modification and societal or organizational set of valued behavior.

\begin{tabular}{|l|l|l|l|}
\hline $\begin{array}{l}\text { Ethical Training and } \\
\text { Development have } \\
\text { direct impact on } \\
\text { behavior modification } \\
\text { and societal or organi- } \\
\text { zational set of valued } \\
\text { behavior. }\end{array}$ & Frequency & $\begin{array}{l}\text { Valid } \\
\text { Percentage }\end{array}$ & $\begin{array}{l}\text { Cumulative } \\
\text { Percentage }\end{array}$ \\
\hline SD & 3 & 0.39 & 0.31 \\
\hline D & 9 & 0.94 & 1.25 \\
\hline U & 29 & 3.02 & 4.27 \\
\hline A & 436 & 45.37 & 49.64 \\
\hline SA & 484 & 50.36 & 100 \\
\hline Total & 961 & 100 & \\
\hline
\end{tabular}

Source: Field Survey (2018)

$S D=$ Strongly Disagree, $D=$ Disagree, $U=$ Undecided, A=Agree, $S A=$ Strongly Agree

Table 3 above reveals that only three respondents represent 0.31 percent of the respondents and nine respondents represent 0.94 percent of the respondents strongly disagreed and disagreed respectively unsubscribed to the opinion of introducing ethical behavior in training and development. The undecided was 3.02. However, 436 respondents (45.37 percent) and 484 respondents (50.36 percent) agreed and strongly agreed that government should introduce ethical behavior for training and development. It was shown that majority of the respondents representing 95.37 percent at least agreed that Ethical education; training and development should be employed as instrument of innovative change in the society which will eradicate or reduce the pattern of fraud in the workforce in Nigeria enterprises. This is in accordance with the findings of Ogundele\&Opeifa (2004).

Table 4 Result of Chi-Square Tests from the Kruskal Wallis Test

\begin{tabular}{|l|l|l|}
\hline Kruskal Wallis Test & Value & $\begin{array}{l}\text { Asymptotic. Sig. } \\
\text { (2-sided) }\end{array}$ \\
\hline Chi-Square & 33.678 & $0.0021^{* *}$ \\
\hline N of Valid Cases & 961 & \\
\hline
\end{tabular}

Source: Field Survey $(2018) * 0.05=$ Level of significant

The Kruskal Wallis test reveals that ethical training and development have direct impact on behavior modification and societal or organizational set of valued behavior.it was 
shown that a P-value of the Pearson chi-square gotten from the independent sample of 0.0021 is less than 0.05 (5\% level of significant) decision rules. This shown that the impact of ethical training and development would be more significant if the youths had earlier exposure to it from secondary and all through to their tertiary education which will eradicate corruption, nepotism and bad leadership in Nigeria.

\section{CONCLUSION}

The study has revealed that there is a moderating influence of training and development on entrepreneurial performance. The finding of this paper shows that Training organized by SMEDAN affects SMEs employment creation. Moreover, Nigerian educational system has contributed positively in training and development which has enhanced entrepreneurial performance in Nigeria and this is in accordance with the findings of Ogundele (2012). Furthermore, It was also revealed that the impact of ethical training and development would be more significant if the youths had earlier exposure to it from secondary and all through to their tertiary education which would have reduced or eliminate bad leadership and governance in Nigeria enterprises. The study concluded that base on the current requirements of the nation, with its privatization and commercialization exercises, our training and development effort should build self-reliance capabilities because this will ensure desirable behavior that will enhance the success of their organization in the fast changing environment. The study also demonstrate the need of developing global skills in Nigerian executives which will helps them to cope effectively with global competitions; these range from self-reliance, ethics or disciplined behavior, man power development and several others.it was emphasized that Nigeria entrepreneurial need skills that will enable them to adjust appropriately to global demands for effectiveness. Nevertheless, the research also concluded that job experience and skills are more effective than any other instrument.it is important to have appropriate training and development techniques of conferences and seminars and that training ranks lowest among the named techniques. Base on the result of findings of this study, the requirement noted in this paper call for disciplined behavior and ethical conduct of the entrepreneurs. Except people are disciplined and exhibit behavior, all training and development efforts will produce little or no results. Our training and development programme should focus on developing creative or innovative individuals who can help to move enterprises forward. A Self-reliant person is a creative individual. More so, Regular seminars and workshops should be organized for entrepreneurs on the importance of systematic approach of training and proper procedure to follow in identifying skills gaps.

\section{REFERENCES}

Adewunmi, E (2004): Africa Trade Unions and the challenge of Globalization: Global trends and Industrial Reflation's in Nigeria. A book of Reading, Faculty of Business Administration, University of Lagos Akoka, pp. 57-69,

Ugoji, C., Mordi C, and Ajonbadi, H. (2014): An investigation into training and development techniques, prospects and challenges in Nigeria Banks. J.Res. Int.Bus. Manag, vol. 4(2) pp.37-44.

Ajonbadi (2017): An investigation on the role of entrepreneurship Education In Promoting Management Entrepreneurial Capabilities: Evidence from some Selected Organizations in Lagos State Nigeria. International Journal of Entrepreneurship Innovation and Management, Kwara State University Malate Nigeria, vol.2, no. 2 \& 3, pp. 37 - 54 .

Armstrong M. (2009): Armstrong handbook of human resources practices (11th Ed). London. Kogan Page Limited.

Creswell, J. W. (2009): Educational research Planning, conducting and evaluating quantitative and qualitative research. (2nd Ed) Upper Saddle River, N.J: Pearson Education.

Dawson, C. and Henley, A., (2012): Push versus pull entrepreneurship: an ambiguous distinction. International Journal of Entrepreneurial Behavior \& Research, 18(6), pp.697-719

Easterby-Smith, M., Thorpe,R.,\& Jackson,P.R (2011): Management Research. 3rd Eds, London, SAGE Publications.

Galloway, L., \& Brown, W. (2002): Entrepreneurship education at university. A driver in the creation of high growth firms? Education \& Training'. Vol.44, no. 8/9, pp. 398-404.

GEM (2008): 'GLOBAL Entrepreneurship Monitor Executive Report'. 2008. GEM

Klapper, R. (2004): Government goals and entrepreneurship education: An investigation at Grand Ecole in France. Education \& Training vol.46 no.3, pp.127-137

Kowo, S \& Kadiri, B. (2018): An Investigation of the Role of Entrepreneurship Agencies for Entrepreneurship Development in Nigeria. Developing Country Studies. USA www.iiste.org, vol.8, No.6, pp.18 - 27

Kowo, S., Sabitu, O. and Adegbite, G. (2018): Influence of competitive strategies on corporate performance of small and medium enterprises: A case from Nigeria'. Agricultural and Resource Economics: International Scientific E-Journal, Kharkiv Petro Vasylenko National Technical University of Agriculture Ukraine. vol. 4, no. 3, pp. 14-33. URL: www.arejournal.com.

Kuratko, D.F., (2005): The emergence of entrepreneurship education: Development, trends and challenges. Entreprenuership Theory and Practice, pp.557-597.

Lalkaka, R., (2003): Business incubators in developing countries: characteristics and performance. International Journal of Entrepreneurship and Innovation Management, 3(1-2), pp.31-55.

Lee, S.M., Chang, D. and Lim, S.B., (2005): Impact of entrepreneurship education: A comparative study of the US and Korea. The International Entrepreneurship and Management Journal, 1(1), pp.27-43.

Lin, C., Jiang, J., Wu, Y.J. and Chang, C., (2011): Assessment of commercialization strategy using R\&D capability. Industrial Management \& Data Systems, 111(3), pp.341-369. 
Matuluko, M., (2015): Nigeria's Communications Minister to release new ICT Blueprint in January. [online] Available at: $<$ https://techpoint.ng/2015/12/28/nigerias-communicationsminister-to-release-new-ict-blueprint-in-january/> [Accessed 11 April 2016].

Mordi, C., Mmieh, F., \& Ojo, S, (2013): An exploratory study of Managers, perspectives of work life balance in Nigeria: A case analysis of the Nigeria banking sector'. Thunderbird International Business Review, vol.55, no.1, pp.55-75.

Moberg, K. (2014): Two approaches to entrepreneurship education: The different effects of education for and through entrepreneurship at lower secondary level'. International Journal of Management Education, In Press.

Melodi, G.O. (2006): Module 3- Managing your own business: Entrepreneurship and corporate governance programme'. University of Lagos, Akoka.

Ogundele O.J.K. (2000): Determinants of entrepreneurial emergence, behavior and performance in Nigeria'. Unpublished PHD Thesis, University of Lagos Akoka.

Ogundele O.J.K. (2005): Ethical Education Manpower in Manpower development in Nigeria'. Knowledge Review, vol.2, no.1, Nov.

Ogundele O.J.K. (2012): Management and Organization: Theory and Behavior. 2nd Ed, Lagos, Molofin Nominees.

Ogundele, O.J.K and Opeifa, A.Z. (2004a): Factors that affect entrepreneurial emergence behavior and performance in Nigeria. Abuja Management Review, Vol.1 No 2, pp.1-19.

Ogundele, O.J.K and Opeifa, A.Z. (2004b): Importance of Ethical Education in Economic and Social Reconstruction. Nigeria Journal of Curriculum and Instruction, Vol 12, No 3, pp.164-169

Ogundele, O.J.K and Olayemi, O.O. (2004): Entrepreneurial Education and Social Economic Reconstruction. Nigeria Journal of Curriculum and Instruction, Vol 12, No 3, pp.164-169

Otokiti, S O. (2013): Institutional roles in entrepreneurship development in Nigeria'. Landmark

University Entrepreneurship Model, paper presented on the occasion of the 2nd entrepreneurship Director conference of kwara State University Malete Nigeria.

Osuagu, L. (2006): Small Business and Entrepreneurship Management'. Lagos, Grey Resources Limited.

Shaker, A.Z. (2011): Entrepreneurial capability: Opportunity pursuit and game changing. paper presented at the DRUID 2011.

Sule, M. (2014): The role of entrepreneurship education on Job creation among youths in Nigeria'. International Letters of Social and Humanistic Sciences.ISSN:2300-2697, vol.15 pp.8796.

SMEDAN. (2012): Survey report on micro, Small and Medium Enterprises (MSMEs) in Nigeria National MSME collaborative survey. Collaboration between National Bureau of Statistics (NBS) and The Small and Medium Enterprises Development Agency of Nigeria (SMEDAN). May 2014. http://www.smedan. gov.ng/images/collaborative\%20survey\%20report.smedan

nbs.pdf 2/9/16,

Snyder, J. D. (2011): A global review of innovative practices in regional SME exporting strategies and foreign direct investment attraction. DRAFT, Center for Community and Economic Development, Michigan State University
Spender, K. (2002): Learning by knowledge intensive firms. Journal of Management Studies. Vol.29, no.6, pp.713-740.

Stefanovic, I., Ljubodrag, R. and Sloboda, P. (2011): Entrepreneurs Motivational Factors: Empirical Evidence from Serbia. Serbian Journal of Management, vol.6, no.1, pp.73- 83.

Stefanovic, I., D. Milosevic \& Miletic (2009): Significance and Development Problems of SMEs in Contemporary Market Economy. Serbian Journal of Management, no.4, no.1, pp.127136.

Swierczek, F., \& T. T. Ha (2003): Motivation, Entrepreneurship, and Performance of SMEs in Vietnam. Journal of Enterprise Culture, vol.11, no.1, pp.47-68

Starr, J.E. \& Fondas, N. (1992): A model of entrepreneurial socialization and organization formation. Journal of Entrepreneurship Theory and Practice, vol.1, no.7, pp.67-76.

Stewart, T. (1998): 'Knowledge, The appreciating commodity. Fortune'. October, pp.199-200.

Stillman, S. (2003): The location of new firms and the life cycle of industries. Journal of Small Business Economics, vol. 2 , no. 2 , pp.265-281.

Subchat, U. (2008): Market orientation and performance within community enterprises in Upper Northeastern Region of Thailand. International Conference. Sustainability in Higher Education: Directions for change. Edith Cowan University, Perth Western Australia. http://ro.ecu.edu.au/ceducom/56.

Tavis, D.J (2007): Mature regionalism and the genesis of functional projects: Educational regionalism in small and micro states. Journal of Globalization, Societies and Education vol.15, pp.1-17.

Thomas, (2013): Entrepreneurship: A working definition. Harvard Business Review.

Udo-Aka.U. (1987): Training Institutions in Nigeria, Types, Structures and programmes. Internal Memoirs of the Director General Centre for Management Development.

Zahraden. U. A (1981): Management Training and Development in Nigeria. Centre for Management Development. 
